Original Research

\title{
Effect of Anion Surfactants on the Adsorption of Polycyclic Aromatic Hydrocarbons on Sediment under Estuarine Mix Conditions
}

\author{
Xiaojie Qian ${ }^{1}$, Kai Liu ${ }^{2 *}$, Hairui Yao ${ }^{3}$, Xiongfei Yin ${ }^{4}$, Guangtao Zhao ${ }^{5}$, \\ Bingchen Wang ${ }^{6}$, Haimei $\mathbf{L i}^{7}$ \\ ${ }^{1}$ Fujian Institute of Tropical Crops, Zhangzhou, China \\ ${ }^{2}$ Bureau of Marine Development and Fisheries of Dongying Municipality, Dongying, China \\ ${ }^{3}$ School of Natural and Applied Sciences, Northwestern Polytechnic University, Xian, China \\ ${ }^{4}$ China Academy of Building Research, Beijing, China \\ ${ }^{5}$ Department of Anatomy, School of Basic Medicine, Binzhou Medical University, Yantai, China \\ ${ }^{6}$ College of Environment and Safety Engineering, Qingdao University of Science and Technology, Qingdao, China \\ ${ }^{7}$ Yantai Engineering and Technology College, Yantai, China
}

Received: 5 February 2019

Accepted: 8 May 2019

\begin{abstract}
We investigated the adsorption of phenanthrene (PHE) onto estuarine sediment with varied salinity and concentrations of anionic surfactant (sodium dodecyl benzene sulfonate, SDBS). It is a critical step for better understanding of the migration of polycyclic aromatic hydrocarbon (PAH) pollutants to seawater. The concentration of PHE in the experimental system was detected by a fluorescence spectrophotometer and the results were expressed by partition coefficient (in terms of $\mathrm{K}_{\mathrm{d}}$ ). It found that the salinity promoted and the SDBS inhibit the adsorption of PHE onto sediment in a single system. The combination effect of SDBS and salinity enhance this adsorption behavior but varied significantly with the ratio of salinity to surfactant. It is a confirmed fact that the mobility of phenanthrene in water increased with the combination of the salinity and SDBS. It would lead to the pollution of PHE change from point model to mobility model and increase its flux into the sea. However, the mechanism of those adsorption behaviors is unclear and may relate to the interactions between sediment and SDBS, SDBS and salinity, and sediments and salts, which need further study.
\end{abstract}

Keywords: phenanthrene, surfactant, sediment, estuary

*e-mail: kliu@yic.ac.cn 


\section{Introduction}

Polycyclic aromatic hydrocarbons (PAHs) refer to the compounds composed of two or more benzene rings obtained by high temperature in a linear, angular or string arrangement [1]. Those compounds have great environmental hazards such as carcinogenesis, mutagenicity, and distortion, which has been significantly released into the environment with human activities [25]. The adsorption onto sediment is one of the main retention behaviors of PAHs in the environment because of its high hydrophobicity [6-8]. And this behavior could affect by salinity and the organic matter of the ambient soil or sediment solution environment. Salinity mainly changed the properties of the solubility of the PAHs, and structure of the sediment or soil in order to increase the fixation of PAHs in the sediment [9]. However, the opposite effect of this behavior was also found. The increase in salinity, especially the $\mathrm{Ca}^{2+}$, inhibit the adsorption of PAHs onto sediments. This phenomenon is attributed to the change in the characteristic of the organic matter in the sediment by inorganic ions [10]. Therefore, the geochemical behavior of PAHs in saline water is complicated. Most researchers attributed this phenomenon to salting out rather than changing the role of organic matter in the adsorbate [11-12].

Surfactants are agents commonly used to repair polycyclic aromatic hydrocarbon pollution in sediment [13-14]. It could affect the migration and transformation of PAHs in the environment by changing the solubility, desorption, and biodegradability of this pollution in the sediment [15-16]. However, the surfactants are also a contaminant. The concentration of this compound in water and sediment has been on the rise in recent years [17-18]. Hence, surfactants may affect the biogeochemical behavior of PAHs in some watersediment environments. At this stage, most researchers attributed the repair of $\mathrm{PAH}$ pollution in terrestrial sediment [19]. There have been few studies on the biogeochemical behavior of PAHs in the water-sediment area with a variety of contaminants and large changes in salinity gradients. The estuary area is an important channel for pollutants to enter the ocean. This region has dramatically varied salinity and physicochemical factors that could affect the characteristics of the biogeochemical behavior of PAHs and surfactants. Therefore, researching and revealing the adsorption behavior of PAHs onto the sediment in the presence of surfactants in an estuary water-sediment environment is necessary. Our study is a critical step for better understanding the migration and fate characteristics of PAHs in a river-ocean intersection environment.

Phenanthrene has a typical polycyclic aromatic hydrocarbon structure and is recognized as one of the carcinogens to be controlled [20]. This contamination is widely distributed in the environment, which includes sediments, water, animals and plants, and even in remote island plastic residues [20-22]. Furthermore, phenanthrene also has significant bioaccumulation in benthic organisms, plants, and even microorganisms [2324]. Therefore, it would create enormous environmental and health risks. In general, it is necessary to study the geochemical behavior of phenanthrene, which is important evidence to clarify the contamination process of PAHs in the environment. In this research, adsorption experiments were conducted to investigate the geochemical behavior of phenanthrene in a watersediment system with estuarine mix conditions. Because the dissolved organic matter in the estuarine is complicated [25-26], the situ river water (not contain salinity) after removal of organic matter is used. In this study, we only focused on the role of the salinity and SDBS in the fractionation of phenanthrene in a seawater-sediment environment. The effects produced by living organisms were not taken into account.

\section{Materials and Methods}

\section{Regents and Experimental Apparatus}

The regents used in this research were guarantee (GR) grade, and the phenanthrene and surfactant (sodium dodecyl benzene sulfonate, SDBS) were supplied by Sigma-Aldrich China Inc. The other regents were supplied by Sinopharm Chemical Reagent Co., Ltd. The material of the experimental reactor was polytetrafluoroethylene (PTFE), which was highly inert to the phenanthrene and SDBS used in the experiment. These controls could eliminate and decrease the errors introduced by the interaction between regents and rector. The sample collectors were brown amber glass bottles (CNW) supplied by ANPEL Laboratory Technologies (Shanghai) Inc. The experimental apparatus was first cleaned with $10 \%$ Decon 90 and soaked in $10 \% \mathrm{HNO}_{3}$ for $24 \mathrm{~h}$. Then the apparatus was rinsed five times with Q-water (18.2 M $\Omega$-cm, PALL) and dried in a clean bench [27-28]. The water used in this study was the surface water from the estuary area of the Yellow River and the sample process derived from previous research [27-28]. About $4 \mathrm{~L}$ water was sampled and the sample site is shown in Fig. 1. The sediment used in this study was the $>63 \mu \mathrm{m}$ fraction of the surface sediment, and the sampling process followed a previous study [29]. The $>63 \mu \mathrm{m}$ fraction sediment was filtered by nylon mesh and dried in a clean bench. The sampled water was UVirradiated for $24 \mathrm{~h}$ in a quartz rector to eliminate the dissolved organic matter before use $(\mathrm{S} \approx 0, \mathrm{DOC}<0.02$ $\mathrm{mg} \mathrm{L}^{-1}$ ). The stock solution of $1000 \mathrm{mg} \mathrm{L}^{-1}$ (w/v) of phenanthrene was prepared in methanol and the SDBS stock solution of $0.1 \mathrm{~mol} \mathrm{~L}^{-1}$ was prepared in natural UV-irradiation water (NUVW) before the beginning of each experiment.

\section{Adsorption Studies}

The adsorption studies were carried out in a $300 \mathrm{ml}$ PTFE tank with a lid customized by Nanjing 


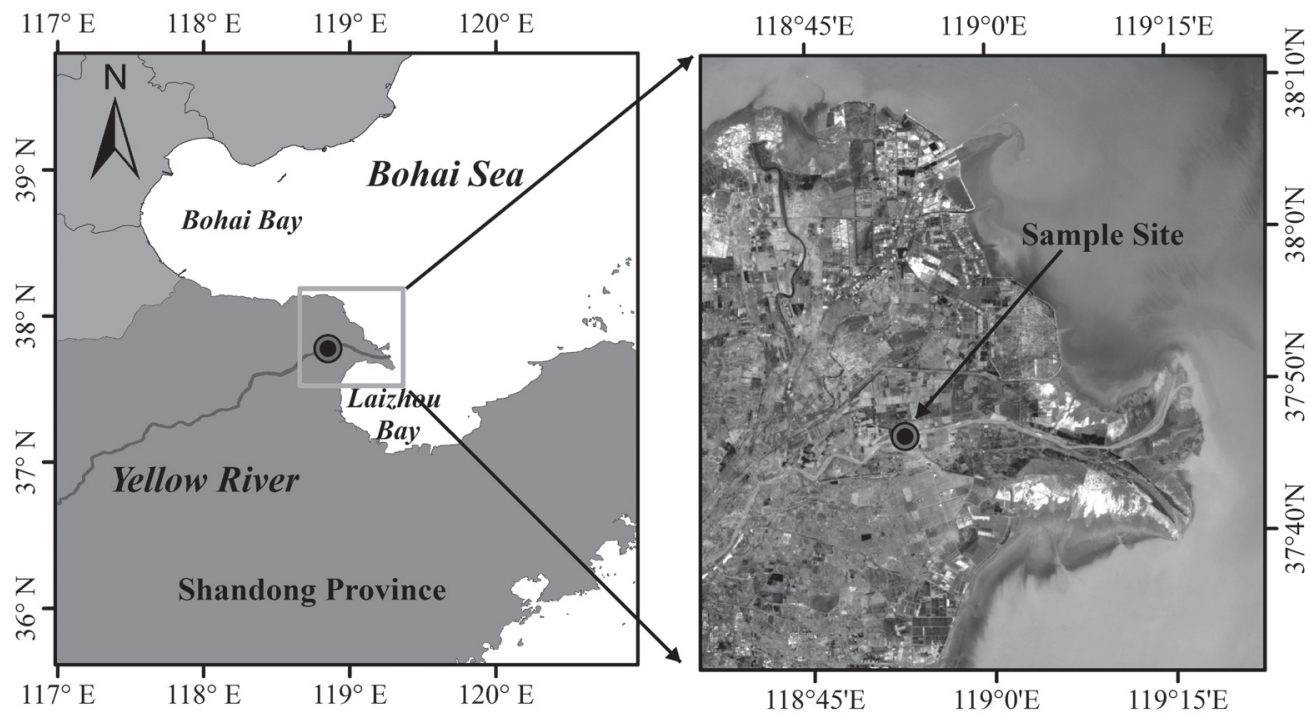

Fig. 1. Black point with red cycle is the location of sampling water and sediment.

Nick technology development co., Ltd. The schema of the adsorption process is shown in Fig. 2. Four types of solution environment were conducted to investigate the effect of salinity $(\mathrm{S}), 0,5,15,35$, respectively, on the phenanthrene adsorption on the estuarine sediment. The artificial seawater, $\mathrm{S}=35$, was prepared in NUVW according to the standard method D1141-98 [30]. The different salinity was obtained by diluting the artificial seawater $(S=35)$. The experiment was conducted according to the following brief process. $1.000 \mathrm{~g}$ sediment was transferred to $300 \mathrm{ml}$ PTFE tank and $198 \mathrm{ml}$ of solution was added. The reaction solutions were stirred by a magnetic stirrer under a rotatation speed that accorded the average speed of the sample sited $\left(0.5 \mathrm{~m} \mathrm{~s}^{-1}\right)$ before beginning the reaction. There were three processes: 1) only phenanthrene added; 2) the SDBS added first and stirred $40 \mathrm{~min}$, then the phenanthrene added; 3) the phenanthrene and SDBS were added at the same time. The concentrations of SDBS were $0,0.1,1,5 \mu \mathrm{mol} \mathrm{L}-1$. Those designs aimed to investigate the preferential adsorption of phenanthrene and SDBS by sediments.

The final concentrations of phenanthrene were $0.5 \mu \mathrm{mol} \mathrm{L} \mathrm{L}^{-1}$ which are close to the PAH average concentration of some estuary and costal area [31-32]. The $\mathrm{pH}$ of the solution was adjusted to 8.0 by adding a volume of non-complexing Tris- $\mathrm{HCl}$ buffer solution $(\mathrm{pH} \sim 8.5)$ to maintain it. The volume of the final working solution was $200 \mathrm{ml}$. The experiment was conducted in the dark and sampled at $0.25,0.5,1,2,4,6,8,12,14$ and

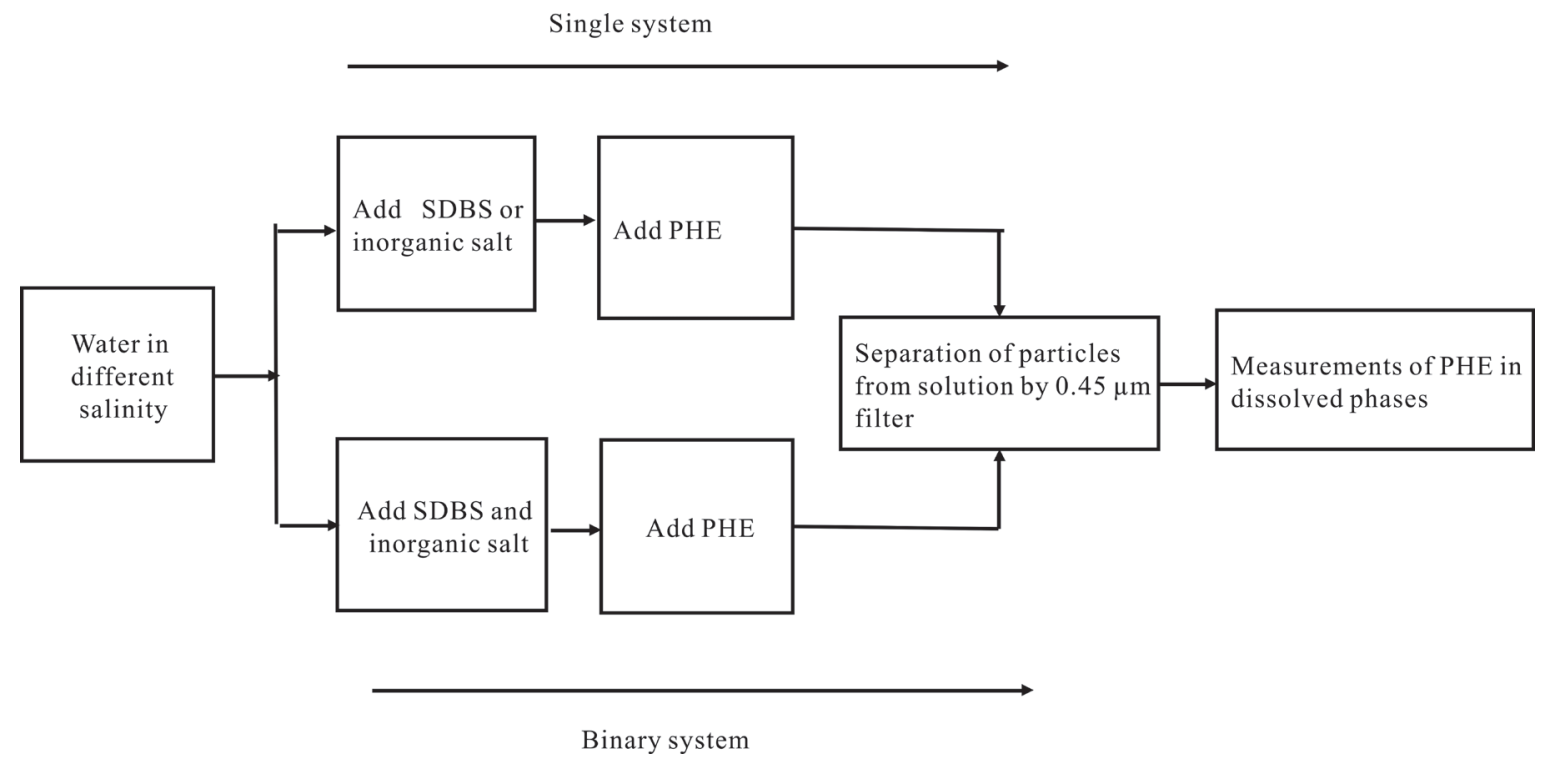

Fig. 2. Flow chart of the adsorption procedures - PHE: phenanthrene; SDBS: sodium dodecyl benzene sulfonate. 
$24 \mathrm{~h}$, respectively. Two controlled trials that only SDBS and sediment in the reaction solutions were conducted. The samples gained in the experiments were filtered by the $0.45 \mu \mathrm{m}$ hydrophilic polyethersulfone membrane (PALL). The separating unit was pretreated with $5 \mathrm{ml}$ of work solution to reduce the retention of phenanthrene and SDBS onto membrane.

The filtered samples were transferred to $10 \mathrm{ml}$ brown amber glass bottles $(\mathrm{CWN})$ and stored at $4^{\circ} \mathrm{C}$ until analysis. The sediment retention in the membrane was freeze-dried in a vacuum freeze dryer. The $\mathrm{pH}$ of the reaction solution should be strictly controlled, for the drastic changes of $\mathrm{pH}$ might result in the formation of colloids, which could interfere with the adsorption significantly. The experimental errors were controlled by conducting three repeat operations.

\section{Instrument and Sample Analysis}

The Q-water (18.2 M $\Omega-\mathrm{cm})$ used in this experiment was produced by PALL pure water system. The salinity of water was detected by an SX751salinity meter (Shanghai San-Xin Instrumentation, Inc.). The concentration of phenanthrene was detected by a fluorescence spectrophotometer (F-7000, Hitachi, Japan). The detection parameters of the F-7000 were as follows. The three-dimensional scanning (3-D Scan): PMT voltage was $700 \mathrm{~V}$; excitation and emission slits were $5 \mathrm{~nm}$; the excitation wavelength and emission wavelength range was $200-600 \mathrm{~nm}$; the excitation and emission wavelength intervals were $5 \mathrm{~nm}$; and scanning speed was $1200 \mathrm{~nm} \cdot \mathrm{min}^{-1}$. The wavelength scanning conditions were PMT voltage: $700 \mathrm{~V}$; excitation and emission slits: $5 \mathrm{~nm}$; and scanning speed: $60 \mathrm{~nm} \cdot \mathrm{min}^{-1}$. The concentrations of phenanthrene were determined by standard curve method. The standard solution of phenanthrene is $0,0.1,0.2,0.5,1 \mu \mathrm{mol} \mathrm{L} \mathrm{L}^{-1}$. The standard solution matrixes were the same as the experimental to eliminate the interference of the different matrixes.

\section{Partition Coefficient}

The adsorption behavior was formulated by the partition coefficient $\left(\mathrm{K}_{\mathrm{d}}\right)$ of phenanthrene between water and sediment phases. It was calculated by a traditional formulation used in many similar experimental systems [33-34]. $\mathrm{K}_{\mathrm{d}}$ was defined here as:

$$
K_{d}=\frac{C_{S}}{C_{W} C_{T}}
$$

...where $\mathrm{C}_{\mathrm{S}}$ represents the concentration of phenanthrene in sediment phase; $\mathrm{C}_{\mathrm{W}}$ is the concentration of phenanthrene in water phase; and $\mathrm{C}_{\mathrm{T}}$ is the total concentration of sediment in the solution. $\mathrm{K}_{\mathrm{d}}$ values are simply reported in terms of $\log \mathrm{K}_{\mathrm{d}}$ (in $\mathrm{L} / \mathrm{kg}$ ).

A fractionation factor $(\mathrm{F})$ is defined as the ratio of $\mathrm{K}_{\mathrm{d}}$ values between different water environments and are used to evaluate the fractionation behavior of phenanthrene by the sediment [34-35].

$$
\mathrm{F}_{\mathrm{A} / \mathrm{B}}=\frac{\mathrm{K}_{\mathrm{d}, \mathrm{A}}}{\mathrm{K}_{\mathrm{d}, \mathrm{B}}}
$$

...where $\mathrm{K}_{\mathrm{d}, \mathrm{A}}$ and $\mathrm{K}_{\mathrm{d}, \mathrm{B}}$ are the partition coefficients of phenanthrene in $\mathrm{A}$ and $\mathrm{B}$ solutions, respectively. $\mathrm{F}_{\mathrm{A} / \mathrm{B}}$ is the fractionation factor between $\mathrm{A}$ and $\mathrm{B}$. When the $\mathrm{F}_{\mathrm{A} / \mathrm{B}}>1$ or $<1$, the sediment preferentially absorbs phenanthrene in A over B or B over A solutions. When $\mathrm{F}_{\mathrm{A} / \mathrm{B}}=1$, the adsorption of phenanthrene on sediment was not affect by the salinity or SDBS.

Table 1. Parameters including the regression equation, relative standard deviation (RSD), and the quantification limits of the instrument

\begin{tabular}{|c|c|c|c|c|}
\hline Solution & Regression equation & RSD & $\mathrm{R}^{2}$ & LOQ \\
\hline NUVW & $y=46587 x+43876$ & $0.1 \pm 0.4 \%$ & 0.9989 & $0.08 \mu \mathrm{mol} \mathrm{L}-1$ \\
\hline $\mathrm{S}=5$ & $y=33261 x+18364$ & $1.5 \pm 1.2 \%$ & 0.9966 & $0.15 \mu \mathrm{mol} \mathrm{L}-1$ \\
\hline$S=15$ & $y=31275 x+15428$ & $4.0 \pm 1.6 \%$ & 0.9949 & $0.23 \mu \mathrm{mol} \mathrm{L}-1$ \\
\hline $\mathrm{S}=35$ & $y=27694 x+13582$ & $8.5 \pm 2.1 \%$ & 0.9905 & $0.33 \mu \mathrm{mol} \mathrm{L}-1$ \\
\hline $0.1 \mu \mathrm{M}$ SDBS & $y=45127 x+44825$ & $0.5 \pm 0.3 \%$ & 0.9993 & $0.09 \mu \mathrm{mol} \mathrm{L}-1$ \\
\hline $1 \mu \mathrm{M}$ SDBS & $y=43156 x+42632$ & $0.7 \pm 0.5 \%$ & 0.9992 & $0.10 \mu \mathrm{mol} \mathrm{L}-1$ \\
\hline $5 \mu \mathrm{M}$ SDBS & $y=45637 x+42159$ & $1.0 \pm 1.0 \%$ & 0.9998 & $0.11 \mu \mathrm{mol} \mathrm{L}-1$ \\
\hline $0.1 \mu \mathrm{M}$ SDBS, $\mathrm{S}=5$ & $y=42130 x+41678$ & $2.0 \pm 0.3 \%$ & 0.9995 & $0.15 \mu \mathrm{mol} \mathrm{L}-1$ \\
\hline $1 \mu \mathrm{M}$ SDBS, $\mathrm{S}=15$ & $y=42072 x+41553$ & $3.5 \pm 0.9 \%$ & 0.9999 & $0.10 \mu \mathrm{mol} \mathrm{L}-1$ \\
\hline $5 \mu \mathrm{M}$ SDBS, $\mathrm{S}=35$ & $y=41280 x+40567$ & $3.5 \pm 1.3 \%$ & 0.9934 & $0.20 \mu \mathrm{mol} \mathrm{L}-1$ \\
\hline $5 \mu \mathrm{M}$ SDBS, $\mathrm{S}=5$ & $y=47689 x+46351$ & $5.8 \pm 2.1 \%$ & 0.9947 & $0.18 \mu \mathrm{mol} \mathrm{L}^{-1}$ \\
\hline $5 \mu \mathrm{M}$ SDBS, $\mathrm{S}=15$ & $y=49012 x+48914$ & $4.7 \pm 1.9 \%$ & 0.9935 & $0.17 \mu \mathrm{mol} \mathrm{L}^{-1}$ \\
\hline
\end{tabular}
(LOQ) of the measured method.

S: salinity; SDBS: sodium dodecyl benzene sulfonate; NUSW: natural UV-irradiation water 


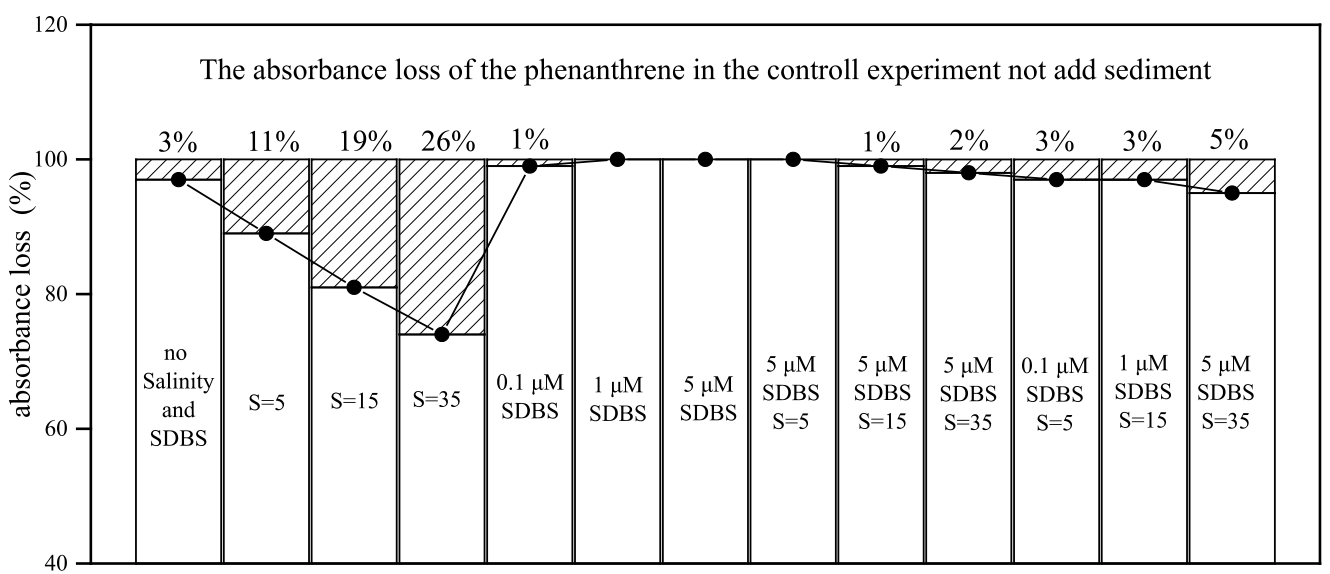

Fig. 3. Absorbance loss of phenanthrene on sediment in binary system - S: salinity; SDBS: sodium dodecyl benzene sulfonate.

\section{Results and Discussion}

\section{Detection and Error Control}

The detection errors were mainly derived from the operation of instruments and the determination matrixes. The errors of instrument operation were controlled by the spiked standard. Once the measured value of the standard sample were lower than the actual value by $10 \%$, the instrument error was considered to be large and recalibration was required. The determination matrixes error was eliminated by the same preparation of standard solutions with the experimental solute. This measure could reduce the interference of the solution matrix on the absorbance of the phenanthrene. Furthermore, the relatively accurate data could be obtained. The $\Delta \lambda$ of PHE was $100 \mathrm{~nm}$ and the excitation wavelength is $248.8 \mathrm{~nm}$. The quantification limits based on $10 \sigma$ (LOQ, ten times of the standard deviation of the blanks, $n=11$ ) of the instrument in different solutions and the relative standard deviation (RSD) between the three measurements of the same sample was less than $5 \%$. The $\mathrm{r}$ of the standard linear fitting equation was $>0.990$. The parameters of the measured method are shown in Table 1.

The errors of this study were mainly from two approaches: the experimental errors and the detection errors of instrument. The experimental errors were mainly consisting of the adsorption of phenanthrene on the vessel wall, the precipitation of phenanthrene, and the operations of the experiments. In this study, we used the total mass balance (expressed by total recovery) of the phenanthrene to investigate the effect of the experimental errors to this study. The total recovery, consisting of the concentrations of phenanthrene in water phase and sediment phase, and the loss in the experiments of phenanthrene. The trend in absorbance can reflect the loss of phenanthrene introduced by the different solution systems. The results are shown in Fig. 3. Some slight loss of phenanthrene, about $<5 \%$, was observed in the SDBS-salinity environment (Fig. 3). The average total recoveries of phenanthrene in this binary system ranged from $94.8-100 \%$. However, the loss of phenanthrene increased in the presence of salinity only. This may be the salting out of the PHE, which make the precipitation of these compounds. The slight loss of PHE in low concentrations of SDBS and blank system $(S=0)$ mean that there is another factor affecting adsorption, which might be the residual colloidal organic matter in the natural water. It has been proven that phenanthrene prefers to transfer into the soil containing dissolved organic matter [36-37]. Hence, the behavior of phenanthrene in the natural estuary water-sediment might be affected by more geochemical factors. In this study, the concentration of phenanthrene in sediment phase was calculated by the total concentration of phenanthrene minus the concentration of phenanthrene in the water phase.

\section{The Single Effect of Salinity and SDBS}

The adsorption behaviors of phenanthrene on sediments in different salinities with time are shown by the partition coefficient $\left(\log K_{d}\right)$ in Fig. 4a) (Eq. 1). The adsorption equilibrium time was $12 \mathrm{~h}$ in those experimental conditions. In the 0 ambient salinity experiment, the adsorption of PHE on sediment first increases in $0-2 \mathrm{~h}$, and then decreases in 2-24 $\mathrm{h}$ stages. The minimum adsorbance was the equilibrium adsorption capacity of phenanthrene in this experimental condition. From Fig. 4, we could find that those parameters were changed with the increase in salinity. The time of maximum adsorption was longer than $0.5 \mathrm{~h}$. The absorbance of phenanthrene occurred in a recurring increase when the minimum absorbance (less than equilibrium adsorption capacity) appeared at 2 h. Furthermore, the $\log K_{d}$ (Eq. 1) showed greater fluctuations in no equilibrium stage in the salinity system than in 0 ambient salinity. It could be found that salinity enhances the adsorption of phenanthrene onto sediment (Fig. 4a). However, this phenomenon may be related to the mineralization of phenanthrene in salt water [38]. The cations existing in the water precipitated the phenanthrene to the sediment, resulting 

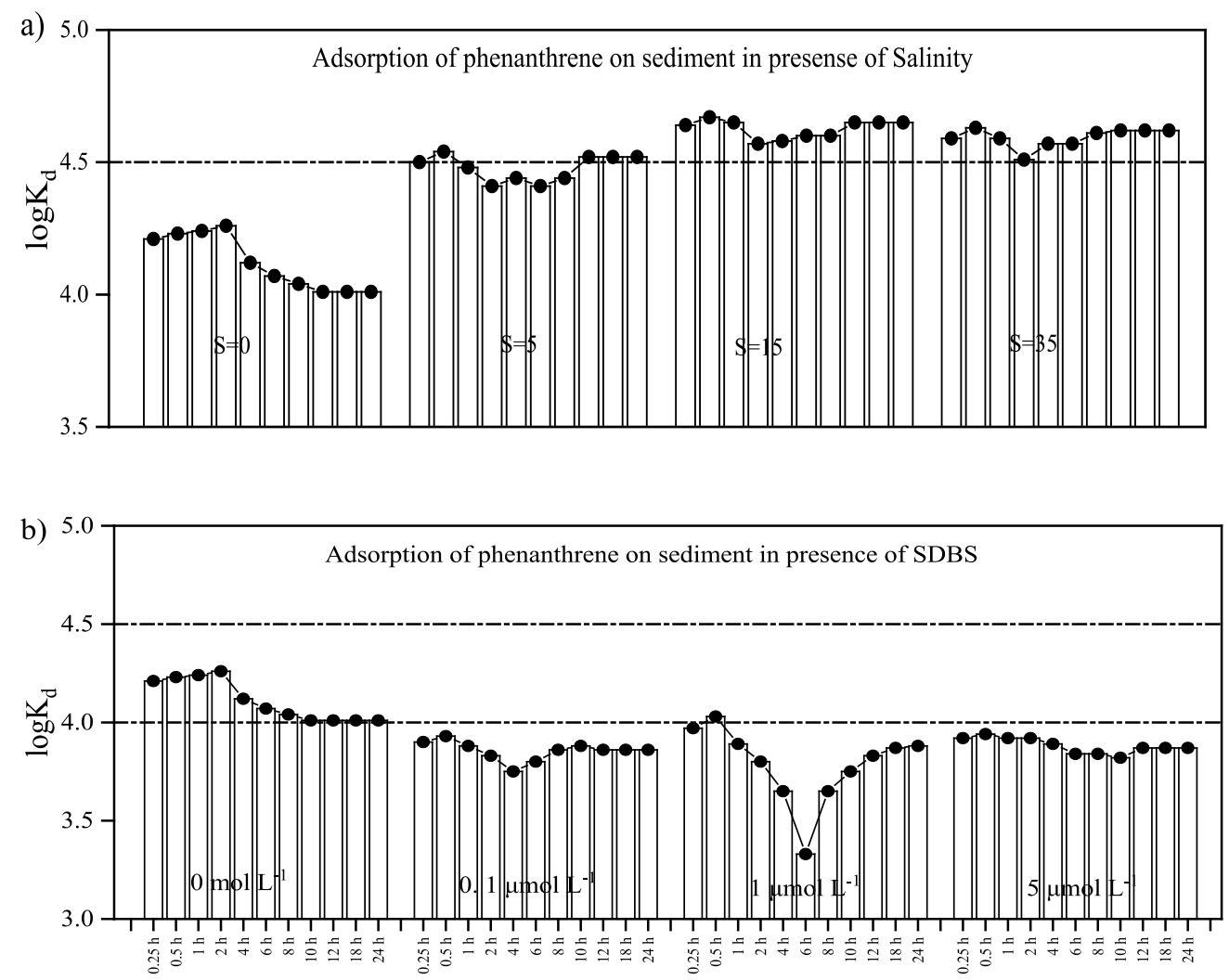

Fig. 4. Partition coefficients $\left(\log K_{d}\right)$ of phenanthrene on sediment in single system - a) S: salinity; b) SDBS: sodium dodecyl benzene sulfonate.

in an enhancement of the absorbance. The absorbance of phenanthrene in different ambient salinities not having sediment was investigated and the results show in Fig. 3. The absorbance of the phenanthrene in the water phase decreased with the increase of salinity. The salt out of PHE might be the main factors increasing adsorption. However, this mineralization varies with the species of cations. The $\mathrm{Ca}^{2+}$ may have a higher effect for increasing the mineralization of phenanthrene than $\mathrm{Na}^{+}$[39]. In addition, the salinity also changes the structure of organic matter in the sediment to affect the adsorption of phenanthrene [40-41]. This might be the fluctuations of $\mathrm{K}_{\mathrm{d}}$ in the ambient salinity experiment. In this study, we only investigated the effect of the salinity, and other reasons were not taken in account. In all, the salinity enhanced the adsorption of phenanthrene onto sediment.

The effect of the SDBS on adsorption behaviors of phenanthrene onto sediment in the natural water with time showed in Fig. 3b). The equilibrium time of all adsorption was delayed 2 hours in the presence of SDBS. The adsorption parameters were also changed with the addition of the SDBS. The time advance of maximum adsorption and a recurring increase adsorption behavior were also observed. However, the change trend of the log $\mathrm{K}_{\mathrm{d}}$ was different. The time of the minimum adsorption was delayed, and the hysteresis was more pronounced with the increase of the SDBS concentration. When the concentration of SDBS in the solution was the highest, the lag time of the minimum adsorbance can reach $10 \mathrm{~h}$. In addition, a very dramatic drop of the $\log \mathrm{K}_{\mathrm{d}}$ was observed with $1 \mu \mathrm{mol} \mathrm{L}{ }^{-1}$ of the SDBS. Moreover, it could find that SDBS hinders the adsorption of the phenanthrene onto sediment. This phenomenon might be related to the solubilization of phenanthrene in the presence of SDBS in the solution. The surfactants could change the polarity of phenanthrene in the solution and inhibit the mineralization of these PAHs in water [42-45]. The absorbance of phenanthrene in different ambient SDBS was also investigated and the results are shown in Fig. 3. There was no evident decrease in absorbance, which showed that phenanthrene mainly remains in the water phase. However, the solubilization alone was not sufficient to explain the phenomenon that SDBS hinders the adsorption of phenanthrene onto sediments. This was due to the sediment used in this study containing an amount of organic matter capable of adsorbing phenanthrene [46-47]. Hence, this inhibitory effect might also be due to the adsorption of phenanthrene by SDBS [48]. In addition, the SDBS also could be adsorbed onto the sediment to occupy the adsorption site [49-52].

From the adsorption curve, the salinity and SDBS enhanced or inhibited the adsorption of phenanthrene by changing the solubilization [43-44] or the surface of adsorbent [52]. However, the adsorption curve of the phenanthrene in the natural water did not contain 


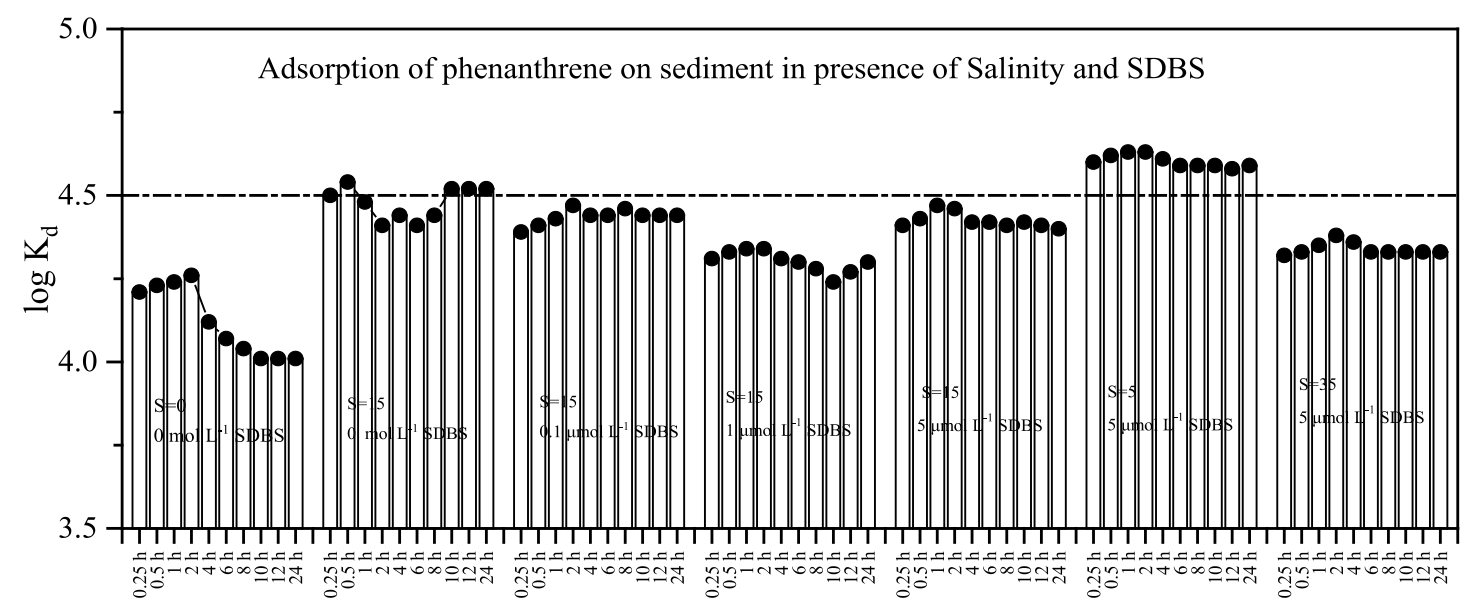

Fig. 5. Partition coefficients $\left(\log \mathrm{K}_{\mathrm{d}}\right)$ of phenanthrene on sediment in binary system - S: salinity; SDBS: sodium dodecyl benzene sulfonate.

any disruptors and also did not follow the general adsorption model. When maximum adsorbance was achieved, desorption or another process may make the phenanthrene escape form the sediment (Fig. 5). Moreover, the absorbance of phenanthrene did not decrease in this experimental condition. This phenomenon might be due to the organic matter in sediment or water phases competing for the phenanthrene in the solution. However, the adsorption of phenanthrene on other sediments was not consistent with existing adsorption models [53]. Hence, the adsorption of phenanthrene in the interface between sediment and water might be dominated by the species of the organic matter in soil and water [54-55]. However, the mechanism of that adsorption remains unclear and requires further study.

$\mathrm{F}$ is used to estimate the adsorption priority of the sediment to phenanthrene in different water environments (Eq. 2). $\mathrm{K}_{\mathrm{d}}$ was the partition coefficient at the adsorption equilibrium (Eq. 1). Most of the $\mathrm{F}_{\mathrm{S} / \mathrm{SDBS}}>1$ indicate that salinity promotes the transfer of phenanthrene from water to sediment. However, the $\mathrm{F}_{\mathrm{S} / \mathrm{SDBS}}<1$ also appeared at another sample time, indicating that other substances in the solution participated in the adsorption of PHE onto sediment. For the change of $\mathrm{F}_{\mathrm{N} / \mathrm{SDBS}}$, all the values were more than 1, indicating that the SDBS inhibits the transfer of phenanthrene to sediment.

\section{Combined Effect of Salinity and SDBS}

The migration of phenanthrene is often affected by a combination of factors. The salinity gradients and different amibent SDBS in the estuary area may result in various characteristics of phenanthrene. Different concentration ratios of SDBS to salinity (Figs 4b and 5) were used in the study (the unit of SDBS was

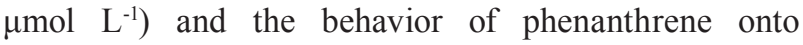
sediment (expressed by $\log \mathrm{K}_{\mathrm{d}}$, calculated by Eq. 1) are shown in Fig. 5. The equilibrium of phenanthrene adsorption onto sediment was broken by the combined effect of the SDBS and salinity. Adsorption equilibrium appeared only when the ratios of Salinity and SDBS was 5:0.1 (Fig. 5). When the salinity was certain, the adsorption behavior of phenanthrene onto the sediment changes differently when the SDBS increased (Fig. 5). The higher the concentration of SDBS, the closer the adsorption behavior of phenanthrene onto sediment to the adsorption that occurred in no interfering substances environment. Moreover, some different behavior was observed in an experimental environment with certain SDBS concentrations. The change of the $\mathrm{K}_{\mathrm{d}}$ become more stable with the increase of salinity, and an abnormal phenomenon observed (Fig. 5). The adsorbance of the phenanthrene onto the sediment enhanced at the ratios of salinity and SDBS, 5:5 and 35:5, and the equilibrium was achieved at highest salinity (Fig. 5). The positive effect of salinity on the adsorption of phenanthrene on sediment was enhanced, while the negative effect of SDBS on the adsorption of phenanthrene on sediment was attenuated. Those phenomena were different with the discussion at 3.2, which might due to the effect of salinity on SDBS and the organic matter in the sediment. Salinity affects the adsorption of phenanthrene by affecting the distribution structure of SDBS in solution in a binary system. For SDBS, its effect on the adsorption of phenanthrene on sediments was mainly achieved by solubilizing phenanthrene in the solution [56]. And this solubilization was dominated by the colloidal SDBS. However, the inorganic cation could enhance the growth of colloidal SDBS and micro-viscosity of the solution [57]. This promotion was more pronounced - especially in low salinity environments [58-59]. By the discussion in 3.2 , the adsorption of phenanthrene on sediments should be inhibited. Nevertheless, the opposite phenomenon occurred and only the loss of SDBS in this binary environment (Fig. 4). This indicates that a strong adsorption environment was formed on 


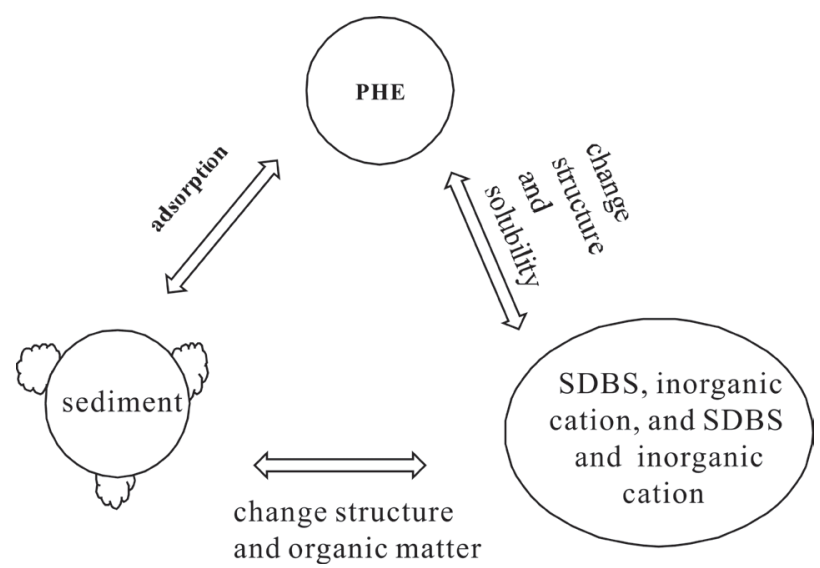

Fig. 6. Process of salinity and SDBS affecting adsorption of phenanthrene on sediment in single a) and binary b) systems.

the sediment. This environment may be formed by the adsorption of colloidal SDBS onto sediment [60-61]. Moreover, the combination of the inorganic cations and SDBS could expand the structure of some components of the sediment [62]. It could enhance the adsorption of phenanthrene on the sediment. Hence, the combination of inorganic cations and SDBS promote the adsorption of phenanthrene on sediments. Different promotional effects may relate to the effect of salinity on SDBS and the combined effect of salinity and SDBS on sediment structure. But further research such as the effect of the species of ions and organic matter was required.

\section{Implications for Phenanthrene Reactivity in the Estuarine Area}

From the discussion in Section 3.1-3.3, the transfer behavior of phenanthrene in the estuarine area was significantly modified by salinity and SDBS. By the absorbance of phenanthrene in different solutions (Fig. 3) and the change of the $\log \mathrm{K}_{\mathrm{d}}$ (Figs 4 and 5, Eq. 1), a possible migration of phenanthrene between the water and the sediment phase under estuarine mix conditions could be inferred. In the freshwater environment, the adsorption parameters cannot fit well with any adsorption kinetics curve in this study. Moreover, some of the equilibrium absorption capacity of phenanthrene was lower than the adsorption amount at every sampling time (Fig. 4). Hence, the migration of phenanthrene in natural freshwater may be dominated by some geochemical factors. The dissolved organic matter in the sediment might be the main factor that affects the transfer of those pollutants [63-64]. The adsorption process mainly occurred between the organic matter on the sediment and the phenanthrene in $0-2 \mathrm{~h}$. While with the organic matter escaping from sediment in stirring conditions [65-66], the phenanthrene adsorbed onto the organic matter enter the water phase again in 2-24 h (Fig. 4). The transfer mechanism is shown in Fig. 6. Ambient salinity environment is another recurring process in which the adsorption increase occurred (Fig. 4b). This might be a result of the effect of inorganic cations on the organic matter and the structure of the sediment [67]. Inorganic cations such as $\mathrm{NaCl}$ and $\mathrm{Na}_{2} \mathrm{SO}_{4}$ could enhance the mineralization of organic matter in the water or sediment phases [68]. Moreover, $\mathrm{Na}^{+}$and $\mathrm{Cl}^{-}$could shift the zero-point charge of the sediment to change the adsorption characteristics [67]. Hence, the phenanthrene interacted with the dissolved organic matter sediment first [69] and then the dissolution fraction of PHE-DOM escaped to the water. In addition, the structure of the sediment expanded by the salinity to enhance the adsorption of PHE on sediment.

In the ambient salinity and SDBS environment, the escape process was weakened and the adsorption behavior was similar to the effect of single salinity (Fig. 5), which might be the result of some more intricate interactions between SDBS and salinity, SDBS and sediment, and salinity and sediment. The first factor was the effect of salinity on the structure of SDBS in solution. $\mathrm{Na}^{+}$or $\mathrm{Ca}^{2+}$ promotes the formation of colloidal intermediates or increases the micro-viscosity of SDBS, resulting in an increase in the adsorption of phenanthrene by SDBS [70]. Furthermore, these formed materials can also be adsorbed by the sediment to alter its surface characteristics [71]. Third, salinity could affect the adsorption properties of sediment to phenanthrene by changing the properties of the sediment [49-50]. However, the strength of these interactions cannot be estimated. There was only some unclear support that could be found from the change of the log $\mathrm{K}_{\mathrm{d}}$ and further study is required.

\section{Conclusions}

Controlled experiments were conducted on adsorption of phenanthrene onto sediment in different salinities and concentrations of SDBS water. The adsorption behavior showed that the SDBS and salinity played an important role on the transfer of phenanthrene from seawater to sediment. The SDBS inhibited the adsorption of phenanthrene onto sediment and salinity promotes this behavior. It appears that the combination of SDBS and salinity promotes the migration of phenanthrene to sediments. However, the adsorption behavior in this binary system was more complicated than in a single environment. This may be due to a variety of factors such as sediment and SDBS, SDBS and salinity, sediments and salts, and organic matter and salts. This was a series of unclear complicated processes and more research was required. However, a fact can be confirmed that the addition of the salinity and SDBS increases the mobility of phenanthrene in the water-sediment environment. In the absence of SDBS contamination, the increase in salinity can promote the precipitation of phenanthrene in the estuary area. However, in the presence of SDBS, the migration of 
phenanthrene to the coastal area could be promoted especially in low salinity areas.

\section{Acknowledgements}

Scientific research was financed by the Natural Science Foundation of Fujian Province of China (No. 2018J01059) for statutory activity.

\section{Conflict of Interest}

The authors declare no conflict of interest.

\section{References}

1. NISBET I.C.T., LAGOY P.K. Toxic equivalency factors (tefs) for polycyclic aromatic hydrocarbons (PAHs). Regul. Toxicol. Pharm. 16 (3), 290, 1992. DOI: 10.1016/02732300(92)90009-X

2. NCUBE S., MADIKIZELA L., CUKROWSKA E., CHIMUKA L. Recent advances in the adsorbents for isolation of polycyclic aromatic hydrocarbons (PAHs) from environmental sample solutions. Trac Trend. Anal. Chem. 99, 101, 2018. DOI: 10.1016/j.trac.2017.12.007

3. BI C., WANG X., JIA J., CHEN Z. Spatial variation and sources of polycyclic aromatic hydrocarbons influenced by intensive land use in an urbanized river network of east china. Sci. Total. Environ. 627, 671, 2018. DOI: 10.1016/j. scitotenv.2018.01.272

4. KYERE V.N., GREVE K., ATIEMO S.M., AMOAKO D., ABOH I.K., CHEABU B.S. Contamination and health risk assessment of exposure to heavy metals in soils from informal e-waste recycling site in Ghana. Emer. Sci. J. 2 (6), 428, 2018. DOI: 10.28991/esj-2018-01162

5. CAI C.Y., YU S.Y., LI X.Y., LIU Y., TAO S., LIU W.X. Emission characteristics of polycyclic aromatic hydrocarbons from pyrolytic processing during dismantling of electronic wastes. J. Hazard. Mater. 351, 270, 2018. DOI: 10.1016/j.jhazmat.2018.03.012

6. JIANG Y., LIN T., WU Z., LI Y., LI Z., GUO Z. Seasonal atmospheric deposition and air-sea gas exchange of polycyclic aromatic hydrocarbons over the Yangtze river estuary, east china sea: implications for source-sink processes. Atmos. Environ. 178, 31, 2018. DOI: 10.1016/j. atmosenv.2018.01.031

7. FOURATI R., TEDETTI, M., GUIGUE C., GOUTX M., ZAGHDEN H., SAYADI S. Natural and anthropogenic particulate-bound aliphatic and polycyclic aromatic hydrocarbons in surface waters of the Gulf of Gabès (Tunisia, southern Mediterranean Sea). Environ. Sci. Pollut. R. 25 (3), 2476, 2018. DOI: 10.1007/s11356-0170641-7

8. CHEN C.W., CHEN C.F. Distribution, origin, and potential toxicological significance of polycyclic aromatic hydrocarbons (PAHs) in sediments of Kaohsiung Harbor, Taiwan. Mar. Pollut. Bull. 63, 417, 2011. DOI: 10.1016/j. marpolbul.2011.04.047

9. YAKOVLEVA E.V., GABOV D.N., BEZNOSIKOV V.A., KONDRATENOK B.M. Accumulation of polycyclic aromatic hydrocarbons in soils and mosses of southern tundra at different distances from the thermal power plant. Eurasian. Soil. Sci. 51 (5), 528, 2018. DOI: 10.1134/ S1064229318030134

10. LEE C.L., KUO L.J., WANG H.L., HSIEH P.C. Effects of ionic strength on the binding of phenanthrene and pyrene to humic substances: three-stage variation model. Water. Res. 37 (17), 4250, 2003. DOI: 10.1016/S00431354(03)00309-9

11. [ADENIJI A.O., OKOH O.O., OKOH A.I. Distribution pattern and health risk assessment of polycyclic aromatic hydrocarbons in the water and sediment of Algoa Bay, South Africa. Environ. Geochem. Hlth. 1, 2018. DOI: 10.1016/j.marpolbul.2018.04.036

12. LIU F., HU S., GUO X., NIU L., CAI H., YANG Q. Impacts of estuarine mixing on vertical dispersion of polycyclic aromatic hydrocarbons (PAHs) in a tidedominated estuary. Mar. Pollut. Bull. 131, 276, 2018. DOI: 10.1016/S0043-1354(03)00309-9

13. WANG X., SUN L., WANG H., WU H., CHEN S., ZHENG X. Surfactant-enhanced bioremediation of ddts and pahs in contaminated farmland soil. Environ. Technol. 39 (13), 1733, 2017. DOI: 10.1080/09593330.2017.1337235

14. KUPPUSAMY S., THAVAMANI P., SINGH S., NAIDU R., MEGHARAJ M. Polycyclic aromatic hydrocarbons (pahs) degradation potential, surfactant production, metal resistance and enzymatic activity of two novel cellulose-degrading bacteria isolated from koala faeces. Environ. Earth. Sci. 76 (1), 14, 2017. DOI: 10.1007/s12665016-6337-3

15. NASCIMENTO R.A., DE ALMEIDA M., ESCOBAR N.C.F., FERREIRA S.L.C., MORTATTI J., QUEIROZ A.F.S. Sources and distribution of polycyclic aromatic hydrocarbons (pahs) and organic matter in surface sediments of an estuary under petroleum activity influence, Todos os Santos Bay, Brazil. Mar. Pollut. Bull. 119 (2), 223, 2017. DOI: 10.1016/j.marpolbul.2017.03.069

16. AEMIG Q., CHERON C., DELGENES N., JIMENEZ J., HOUOT S., STEYER J.P., PATUREAU D. Distribution of polycyclic aromatic hydrocarbons (PAHAs) in sludge organic matter pools as a driving force of their fate during anaerobic digestion. Waste. Manage. 48, 389, 2016. DOI: 10.1016/j.wasman.2015.11.045

17. SHAHAROM S., LATIF M.T., KHAN M.F., YUSOF S.N.M., SULONG N.A., WAHID N.B.A., UNING R., SURATMAN S. Surfactants in the sea surface microlayer, subsurface water and fine marine aerosols in different background coastal areas. Environ. Sci. Pollut. Res. 1-2, 1, 2018. DOI: $10.1007 / \mathrm{s} 11356-018-2745-0$

18. ROYSTON U., TALIB L.M., LING Y.K., YIN C.S., FATIMAH, A., MD FIROZ K., ANDREW BEDURUS E., SURATMAN S. Surfactants in the sea surface microlayer, underlying water and atmospheric particles of tropical coastal ecosystems. Water. Air. Soil. Poll. 229 (9), 305, 2018. DOI: $10.1007 / \mathrm{s} 11270-018-3961-4$

19. LAMICHHANE S., BAL KRISHNA K. C., SARUKKALIGE R. Surfactant-enhanced remediation of polycyclic aromatic hydrocarbons: A review. J. Environ. Manage. 199, 46, 2017. DOI: 10.1016/j.jenvman.2017.05.037

20. CACHADA A., FERREIRA D.S.E., DUARTE A.C. PEREIRA R. Risk assessment of urban soils contamination: the particular case of polycyclic aromatic hydrocarbons. Sci. Total. Environ. 551-552, 271, 2016. DOI: $10.1016 /$ j.scitotenv.2016.02.012

21. SONG H., ZHANG Y., LUO M., GU J., WU M., XU D., XU G., MA L. Seasonal variation, sources and health risk assessment of polycyclic aromatic hydrocarbons in different particle fractions of pm 2.5, in Beijing, China. 
Atmos. Pollut. Res. 10 (1), 105, 2019. DOI: 10.1016/j. apr.2018.06.012

22. YU Y., YU Z., WANG Z., LIN B., LI L., CHEN, X., ZHU X., XIANG M. Polycyclic aromatic hydrocarbons (PAHs) in multi-phases from the drinking water source area of the pearl river delta (PRD) in south china: distribution, source apportionment, and risk assessment. Environ. Sci. Pollut. R. 25 (13), 12557, 2018. DOI: 10.1007/s11356-018-1421-8

23. ZHANG H., CHEN W., SHEN X., MENG Z., YU Y., WHITE J., TAO X., WANG X. Influence of multi-walled carbon nanotubes and fullerenes on the bioaccumulation and elimination kinetics of phenanthrene by geophagous earthworms (Metaphire Guillelmi). Environ. Sci-Nano. 4 (9), 2017. DOI: $10.1039 / \mathrm{C} 7 \mathrm{EN} 00118 \mathrm{E}$

24. WANG H., LI Y., XIA X., XIONG X. Relationship between metabolic enzyme activities and bioaccumulation kinetics of PAHs in zebrafish (Danio Rerio). J. Enviro. Sci. 43, 2017. DOI: $10.1016 /$ j.jes.2017.03.037

25. YANG X., CHEN Z., WU Q., XU M. Enhanced phenanthrene degradation in river sediments using a combination of biochar and nitrate. Sci. Total. Environ. 619-620, 600, 2018. DOI: 10.1016/j.scitotenv.2017.11.130

26. PARA J., COBLE P.G., CHARRIERE B., TEDETTI M., FONTANA C., SEMPERE R. Fluorescence and absorption properties of chromophoric dissolved organic matter $(\mathrm{CDOM})$ in coastal surface waters of the northwestern Mediterranean Sea, influence of the Rhone River. Biogeosciences. 7, 4083, 2010. DOI: 10.5194/bg-7-40832010

27. LI L., LIU J.H., WANG X.J., SHI X.F. Dissolved trace metal distributions and $\mathrm{Cu}$ speciation in the southern Bohai Sea, China. Mar. Chem. 172, 34, 2015. DOI: 10.1016/j. marchem.2015.03.002

28. LIU K., GAO X., LI L., CHEN C.A., XING Q. Determination of ultra-trace pt, pd and $\mathrm{rh}$ in seawater using an off-line pre-concentration method and inductively coupled plasma mass spectrometry. Chemosphere, 212, 429, 2018. DOI: $10.1016 /$ j.chemosphere.2018.08.098

29. TURNER A., CRUSSELL M., MILLWARD G.E., COBELO-GARCIA A., FISHER A.S. Adsorption kinetics of platinum group elements in river water. Environ. Sci. Technol. 40 (5), 1524, 2006. DOI: 10.1021/es0518124

30. ASTM. American Society for Testing and Materials, Standard Practice for the Preparation of Substitute Ocean Water. https://www.astm.org/Standards/D1141.html, 2013.

31. CAI M., DUAN M., GUO J., LIU M., QI A., LIN Y., LIANG J.H. PAHs in the northern south china sea: horizontal transport and downward export on the continental shelf. Mar. Chem. 202, 121, 2018. DOI: 10.1016/j.marchem.2018.03.004

32. LEI M., LIAN-JUN B., LEI S., LIANG-YING L., ZENG E.Y. Polycyclic aromatic hydrocarbons affiliated with microplastics in surface waters of Bohai and Huanghai seas, China. Environ. Pollut. 241, 834, 2018. DOI: 10.1016/j.envpol.2018.06.012

33. AHN C.K., WOO S.H., PARK, J.M. Selective adsorption of phenanthrene in nonionic-anionic surfactant mixtures using activated carbon. Chem. Eng. J. 158 (2), 115, 2010. DOI: 10.1016/j.cej.2009.12.014

34. YANG W., GUO L., CHUANG C.Y. Adsorption characteristics of ${ }^{210} \mathrm{~Pb},{ }^{210} \mathrm{Po}$ and ${ }^{7} \mathrm{Be}$ onto micro-particle surfaces and the effects of macromolecular organic compounds. Geochim. Cosmochim. Ac. 107, 47, 2013. DOI: 10.1016/j.gca.2012.12.039

35. LIN P., CHEN M., GUO L. Effect of natural organic matter on the adsorption and fractionation of thorium and protactinium on nanoparticles in seawater. Mar. Chem. 173, 291, 2015. DOI: 10.1016/j.marchem.2014.08.006

36. MARKIEWICZ M., JUNGNICKEL, C., ARP H.P.H. Ionic liquid assisted dissolution of dissolved organic matter and PAHs from soil below the critical micelle concentration. Environ. Sci. Technol. 47 (13), 6951, 2013. DOI: 10.1021/ es304568w

37. KUPPUSAMY S., THAVAMANI P., SINGH S., NAIDU R., MEGHARAJ M. Polycyclic aromatic hydrocarbons (PAHs) degradation potential, surfactant production, metal resistance and enzymatic activity of two novel cellulosedegrading bacteria isolated from koala faeces. Environ. Earth. Sci. 76 (1), 14, 2017. DOI: 10.1007/s12665-016-6337-

38. PERTSEV A., ARANOVICH L., PROKOFIEV V., BORTNIKOV N., CIPRIANI A. High-salinity seawaterderived fluids and lower-crust hydrothermal mineralization at the vema lithospheric section, Central Atlantic. Proce. Earth. Planet. Sci. 7, 677, 2013. DOI: 10.1016/j. proeps.2013.03.037

39. DUAN L., NAIDU R. Effect of ionic strength and index cation on the sorption of phenanthrene. Water. Air. Soil. Poll. 224 (12), 1700, 2013. DOI: 10.1007/s11270-013$1700-4$

40. WU F., XU L., SUN Y., LIAO H., ZHAO X., GUO, J. Exploring the relationship between polycyclic aromatic hydrocarbons and sedimentary organic carbon in three Chinese lakes. J. Soil. Sediment. 12 (5), 774, 2012. DOI: 10.1007/s11368-012-0498-9

41. ABDULLA H.A.N., MINOR E.C., DIAS R.F., HATCHER P.G. Transformations of the chemical compositions of high molecular weight dom along a salinity transect: using two-dimensional correlation spectroscopy and principal component analysis approaches. Geochim. Cosmochim. Ac. 118 (10), 231, 2013. DOI: 10.1016/j.gca.2013.03.036

42. RODRIGUES A., NOGUEIRA R., MELO LUIS F., BRITO ANTÓNIO G. Effect of low concentrations of synthetic surfactants on polycyclic aromatic hydrocarbons (PAH) biodegradation. Int. Biodeter. Biodegr. 83, 48, 2013. DOI: 10.1016/j.ibiod.2013.04.001

43. ZHAO B., ZHU L., LI W., CHEN B. Solubilization and biodegradation of phenanthrene in mixed anionic-nonionic surfactant solutions. Chemosphere. 58 (1), 40, 2005. DOI: 10.1016/j.chemosphere.2004.08.067

44. WONG J.W.C., FANG M., ZHAO Z., XING B. Effect of surfactants on solubilization and degradation of phenanthrene under thermophilic conditions. J. Environ. Qual. 33 (6), 2015. DOI: 10.2134 /jeq2004.2015

45. LIANG X., GUO C., LIU S., DANG Z., WEI Y., YI X. Cosolubilization of phenanthrene and pyrene in surfactant micelles: experimental and atomistic simulations studies. J. Mol. Liq. 263, 1, 2018. DOI: 10.1016/j.molliq.2018.04.123

46. SHI H.L., ZHU S.H., QIAO Y.M., WANG W., SHI J.J., LI X.L., PANG W.H. Characterization and phenanthrene sorption of organic matter fractions isolated from organic and mineral soils. Environ. Sci. Pollut. R. 25 (16), 15971, 2018. DOI: $10.1007 / \mathrm{s} 11356-018-1814-8$

47. FENG Z., ZHU L. Sorption of phenanthrene to biochar modified by base. Front.Env. Sci. Eng. 12 (2), 1, 2018. DOI: $10.1007 / \mathrm{s} 11783-017-0978-7$

48. WEI Y., LIANG X.J., GUO C.L., DANG Z. Competitive partitioning of phenanthrene in carbon nanomaterials and anionic and nonionic micelles. Colloid. Surface. A. 553, 612, 2018. DOI: 10.1016/j.colsurfa.2018.06.014

49. YANG G.P., DING H.Y., CAO X.Y., DING Q.Y. Sorption behavior of nonylphenol on marine sediments: effect 
of temperature, medium, sediment organic carbon and surfactant. Mar. Pollut. Bull. 62 (11), 2362, 2011. DOI: 10.1016/j.marpolbul.2011.08.036

50. NEMATOLLAHI H., MORADI N., RIYAZINEJAD M., VAHIDI H. Removal of Aliphatic Hydrocarbons from Gas Oil Contaminated Clay Soil via Soil Vapor Extraction. Civil. Eng. J. 4 (8), 1858, 2018. DOI: 10.28991/cej03091120

51. NASIRI E. F., KEBRIA D. Y., QADERI F. An experimental study on the simultaneous phenol and chromium removal from water using titanium dioxide photocatalyst. Civil. Eng. J. 4 (3), 585, 2018. DOI: 10.28991/cej-0309117

52. YU H., ZHU L., ZHOU W. Enhanced desorption and biodegradation of phenanthrene in soil-water systems with the presence of anionic-nonionic mixed surfactants. J. Hazard. Mater. 142 (1-2), 354, 2007. DOI: 10.1016/j. jhazmat.2006.08.028

53. RAMPRASAD C., PHILIP L. Sorption of surfactants and personal care products in indian soils. Int. J. Envion. Sci. Te. 14 (4), 853, 2017. DOI: $10.1007 / \mathrm{s} 13762-016-1188-8$

54. SINGH R.P., KHAN N.U., SRIVASTAVA G. Effect of CPC, Brij-35, and SDBS surfactants on the adsorption and movement of carbofuran in indian soils. Soil. Sediement. Conta. 21 (2), 21, 2012. DOI: 10.1080/15320383.2012.649656

55. PERMINOVA I.V., GRECHISHCHEVA N.Y., PETROSYAN V.S. Relationships between structure and binding affinity of humic substances for polycyclic aromatic hydrocarbons: relevance of molecular descriptors. Environ. Sci. Technol. 33 (21), 3781, 1999. DOI: 10.1021/ es990056x

56. PING L., LUO Y. Phenanthrene adsorption on soils from the Yangtze river delta region under different ph and temperature conditions. Environ. Geochem. Hlth. 41 (7), 267, 2019. DOI: $10.1007 / \mathrm{s} 10653-018-0165-1$

57. LIU J.F., CHEN W.H. Remediation of phenanthrene contaminated soils by nonionic-anionic surfactant washing coupled with activated carbon adsorption. Water. Sci. Technol. 72 (9), 1552, 2015. DOI: 10.2166/wst.2015.357

58. MIYAGISHI S., AKASOHU W., HASHIMOTO T., ASAKAWA T. Effect of $\mathrm{NaCl}$ on aggregation number, microviscosity, and CMC of n-dodecanoyl amino acid surfactant micelles. J. Collo. Inter. Sci. 184 (2), 527, 1996. DOI: $10.1006 /$ jcis. 1996.0648

59. AJITH S., RAKSHIT A.K. Effect of $\mathrm{NaCl}$ on a nonionic surfactant microemulsion system. Langmuir. 11 (4), 1122, 1995. DOI: $10.1021 / \mathrm{la} 00004 \mathrm{a} 015$

60. NIRI M.V., MAHVI A.H., ALIMOHAMMADI M., SHIRMARDI M., KHISHDOST M. Removal of natural organic matter (NOM) from an aqueous solution by $\mathrm{NaCl}$ and surfactant-modified clinoptilolite. J. Water. Health. 13 (2), 394, 2015. DOI: 10.2166/wh.2014.088
61. JAWADUDDIN M., MEMON S.A., BHEEL N., ALI F., AHMED N., ABRO A. W. Synthetic grey water treatment through $\mathrm{FeCl}_{3}$-activated carbon obtained from cotton stalks and river sand. Civil. Engin. J. 5 (2), 2019. DOI: 10.28991/cej-2019-03091249

62. COSULTCHI A., ODRIOZOLA G., MOCTEZUMA A., LARA V.H. Expansion of natural $\mathrm{Na}^{+}$and $\mathrm{Ca}^{2+}$ montmorillonites in the presence of $\mathrm{NaCl}$ and surfactant solutions. Energ. Fuel. 26 (5), 2578, 2012. DOI: 10.1021/ ef 2013375

63. HE Y., MEN B., YANG X., LI Y., XU H., WANG D. Relationship between heavy metals and dissolved organic matter released from sediment by bioturbation/ bioirrigation. J. Environ. Sci-China. 75, 216 (1), 2019. DOI: 10.1016/j.jes.2018.03.031

64. LI M., YATES S.R. Dissolved organic matter and estrogen interactions regulate estrogen removal in the aqueous environment: a review. Sci. Total. Environ. 640, 529, 2018. DOI: $10.1016 /$ j.scitotenv.2018.05.301

65. NOVOTNIK B., CHEN W., EVANS R.D. Uranium bearing dissolved organic matter in the porewaters of uranium contaminated lake sediments. Appl. Geochem. 91, 2018. DOI: 10.1016/j.apgeochem.2018.01.009

66. HONGYUN NIU, DI ZHANG, SHENGXIAO ZHANG, XIAOLE ZHANG, ZHAOFU MENG, YAQI CAI. Humic acid coated $\mathrm{Fe}_{3} \mathrm{O}_{4}$ magnetic nanoparticles as highly efficient Fenton-like catalyst for complete mineralization of sulfathiazole, J. Hazar. Mater. 190 (1-3), 559, 2011. DOI: 10.1016/j.jhazmat.2011.03.086

67. VALLE J., GONSIOR M., HARIR M., ENRICHPRAST A., SCHMITTKOPPLIN P., BASTVIKEN, D., CONRAD R., HERTKORN N. Extensive processing of sediment pore water dissolved organic matter during anoxic incubation as observed by high-field mass spectrometry (FTICR-MS). Water Res. 129, 252, 2018. DOI: 10.1016/j. watres.2017.11.015

68. BERGER V.Y., MITYAEV M.V., SUKHOTIN A.A. Practical wet oxidation experiment to determine concentrations of particulate organic matter in seawater. Oceanology. 56 (2), 307, 2016. DOI: 10.1134/ S0001437016020016

69. LI X.G., LI F.M., MA Q.F., CUI Z.J. Interactions of $\mathrm{NaCl}$ and $\mathrm{Na}_{2} \mathrm{SO}_{4}$ on soil organic $\mathrm{c}$ mineralization after addition of maize straws. Soil Biol. Biochem. 38 (8), 2328, 2006. DOI: 10.1016/j.soilbio.2006.02.015

70. ZHANG J., HE M. Effect of surfactants on sorption and desorption of phenanthrene onto black carbon. Water. Environ. Res. 83 (1), 15, 2011. DOI: 10.2175/106143010x1 2681059116536

71. KIM S.Y., KORETSKY C. Influence of $\mathrm{NaCl}$ and $\mathrm{CaCl}_{2}$ on lake sediment biogeochemistry. Appl. Geochem. 26 (S), 2011. DOI: 10.1016/j.apgeochem.2011.0 
